DOI: https://doi.org/10.18371/fp.1(33).2019.177103

УДК 336.71

\title{
РОЗВИТОК МАЛОГО ТА СЕРЕДНЬОГО ПІДПРИЄМНИЦТВА В УКРАÏНІ: ТРЕНДИ ТА ІННОВАЦІЇ ФІНАНСУВАННЯ
}

\author{
ПАНТСЛСЄВА Наталія Миколаївна, \\ доктор економічних наук, доцент \\ заступник директора Черкаського інституту \\ ДВНЗ «Університет банківської справи» \\ ORCID ID: 0000-0001-6457-6912 \\ e-mail:nnpanteleeva2017@gmail.com
}

\section{ПАНТСЛСЄВА Ксенія Олександрівна}

аспірант, ДВНЗ «Університет банківської справи»

ORCID ID: 0000-0003-3709-1375

e-mail: kseniapantieleeva@gmail.com

\section{ЧМИР Марина,}

магістр Черкаського інституту

ДВНЗ «Університет банківської справи»

e-mail:m.ivanivna95@ukr.net

Анотація. У статті досліджено значення фінансування для розвитку малого і середнього підприємництва (МСП) та виявлено інституиійні фактори, щзо обмежують інклюзію зовнішніх запозичень та стримують розвиток МСП; оцінено сучасний стан фінансово-кредитного забезпечення МСП вітчизняним банківським сектором; доведено значущість МСП для економічного зростання Украӥни та розраховано коефіиієнт їх активності; обгрунтовано можливості фінансових інновачій для розширення зовнішніх джерел фінансування МСП.

Ключові слова: мале i середнє підприємництво, малі та середні підприємства, кредитування, фінансові інновачії, циифрова економіка, ичфрові технології, краудфандінг, краудінвестінг, краудлендінг.

Аннотация. $B$ cmaтье исследовано значение финансирования для развития малого $и$ среднего предпринимательства (МСП) и выявлено институционные факторы, которые ограничивают инклюзию внешних заимствований и сдержсивают развитие МСП; дана оиенка современного состояния финансово-кредитного обеспечення МСП отечественным банковским сектором; доказано значимость МСП для экономического роста Украинь и расчитано коэффициент их активности; обоснованы возможности финансовых инновачий для расширения внешних источников финансирования МСП.

Ключевые слова: малое и середнее предпринимательство, малье и средние предприятия, кредитование, финансовые инновачии, ичифровая экономика, ичифровые технологии, краудфандинг, краудинвестинг краудлендинг. 
Постановка проблеми. Важливість i необхідність розвитку малого i середнього підприємництва (МСП) підтверджує прийняття державної стратегії, серед пріоритетних напрямів якої визначено «створення сприятливого середовища для розвитку МСП, покращення доступу до фінансування, спрощення податкового адміністру-вання, популяризація підприємницької культури та розвиток навчання підприємницьким навичкам, сприяння експорту/інтернаціоналізації, підсилення конкурентоспроможності та інноваційного потенціалу МСП» [1]. У свою чергу, досягнення поставлених стратегічних завдань неможливо без активізації інвестиційно-інноваційної діяльності цього сектору вітчизняної економіки, що, водночас, потребує значних фінансових ресурсів. На сьогодні фінансування МСП переважно пов'язують 3 банківським кредитуванням, менше - iз залученням фінансування 3 боку міжнародних фінансових організацій (МФО), поза увагою залишаються альтернативні джерела і можливості фінансування, у тому числі варіанти тіньової та цифрової економіки, які $\epsilon$ діаметрально протилежними у відношенні ефектів і наслідків свого впливу на економічний розвиток країни.

Аналіз останніх досліджень i публікацій. Останнім часом мале та середнє підприємництво (МСП) стало предметом багатьох наукових дискусій стосовно його значення для відновлення після рецесії та економічного зростання кран світу, подолання бідності та зменшення соціальної нерівності, тощо. Поряд 3 ефектами важливим $\epsilon$ дослідження передумов розвитку МСП, зокрема ефективності фінансового механізму. Ці аспекти в своїх роботах розглядають дослідники вітчизняної та зарубіжних наукових шкіл, зокрема Г. Азаренкова, Д. Андреєв, Д. Васильєва, Дж. К. Ван Хорн, 3. Варналій, В. Геєць, А. Гриценко, М. Долішній, Дж. Кейнс, О. Колодізєв, А. Кузнєцова, Р. Левин, Х. Ліберті, Р. Мертон, Р. Нуреєв, А. Поддерьогін, О. Попов, Д. Рикардо, Л. Саммерс, А. Смит, М. Фрідман, А. Чухно, Й. Шумпетер та інші.

Мета статті полягає в дослідженні когерентності між національними та загальносвітовими трендами, адаптації можливостей фінансових інновацій для підвищення інклюзії зовнішніх запозичень для розвитку МСП в умовах цифрової трансформації фінансового посередництва та посилення дезінтермедіації.

Виклад основних результатів. Незважаючи на складну економічну ситуацію, яка пов'язана зі скороченням обсягів виробництва у системоутворюючих галузях металургії, хімічній промисловості, машинобудуванні та сільському господарстві, внаслідок чого відбулося падіння ВВП (на 5,1\% у 2014 р.), зростанням державного боргу (до 70\% ВВП у 2014 р.), девальвацією національної валюти, нездійсненням очікувань стосовно отримання від $\mathrm{CC}$ преференції щодо зони вільної торгівлі, залежністю від імпорту, несприятливим бізнес-кліматом i низькою інвестиційною активністю, масштабною корупцією $\mathrm{i}$ тіньовою 
економікою на тлі втрати частини Україні відбулося зменшення на 17\% територій на сході України внаслідок відносно 2010 р. загальної кількості військового конфлікту, діяльність підприємництва, а в його структурі МСП набула системної підтримки з частка МСП становила 99,98\%, де боку державної політики.

Але в таких економічних передумомалих - 2,9\%, середніх - 0,85\% та мікропідприємств - 96,26\% (рис. 1). У вах складно очікувати стійкість сукупних обсягах реалізації продукції динаміки розвитку МСП. У 2017 р. в вага МПС постійно зростає (рис. 2).

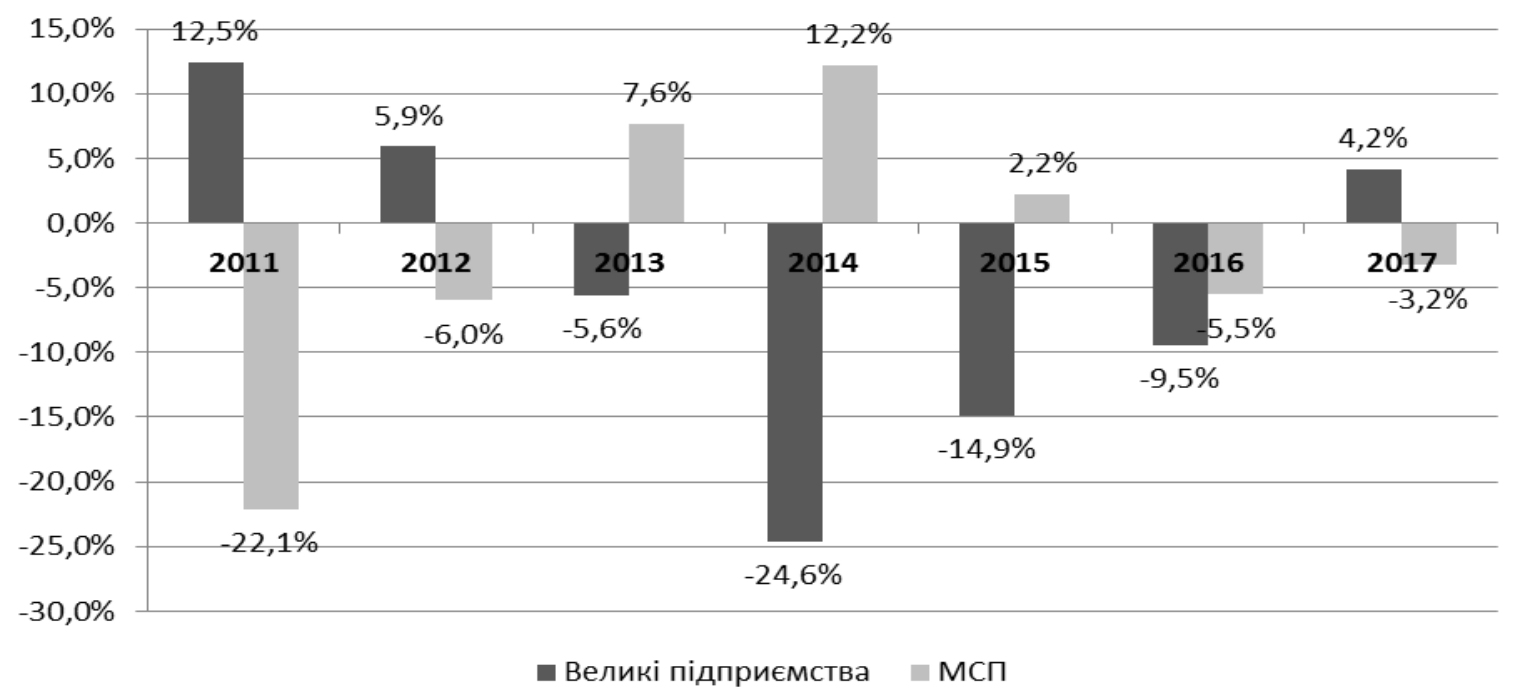

Рис. 1 Динаміка темпів приросту вітчизняних підприємств протягом 2011-2017 pp. Джерело: розраховано автором на підставі опраџювання [2]

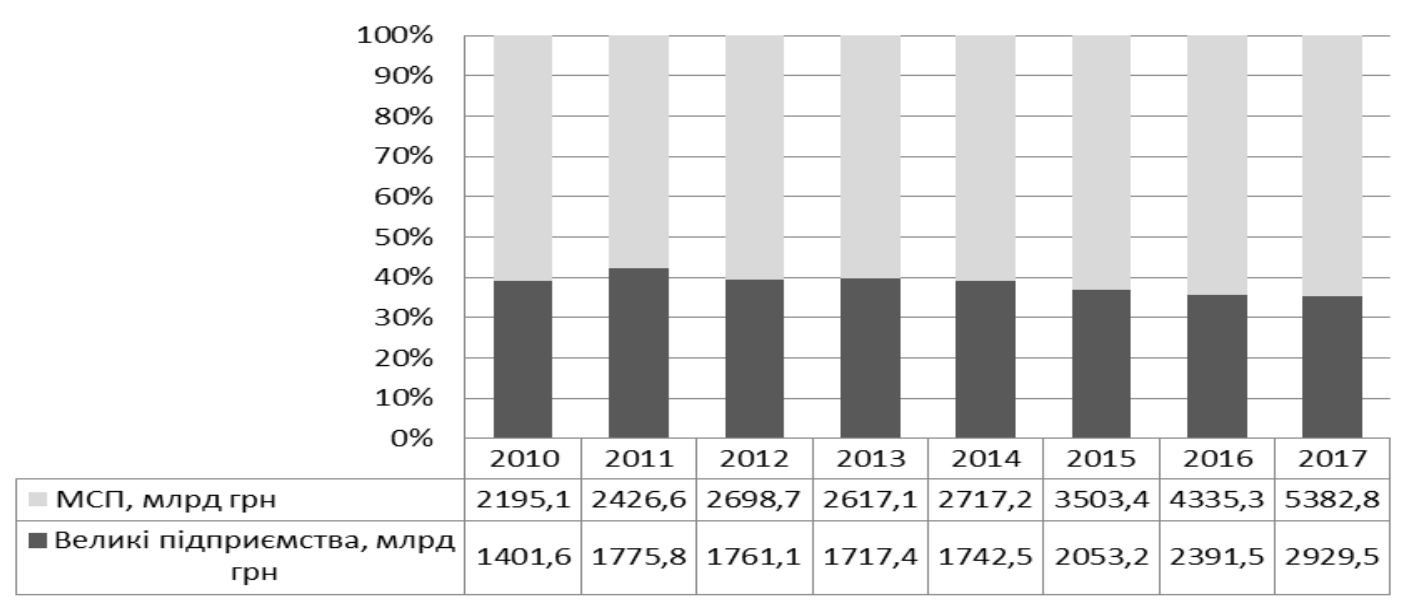

Рис. 2 Динаміка обсягів реалізації продукції вітчизняних підприємств протягом 2010-2017 pp.

Джерело: розраховано на підставі опрацювання [2]

Галузева структура МСП свідчить, поштової та кур'єрської діяльності, що воно найбільш динамічно охороні здоров'я та надання соціальрозвивається в сільському госпо- ної допомоги, фінансової сфері (табл. дарстві, оптової та роздрібної торгівлі, 1). транспорті, складському господарстві, 
Таблиця 1

Структурна характеристика обсягів реалізованої продукції (товарів, послуг) суб’єктів великого, середнього, малого підприємництва в 2017 р. (млрд грн)

\begin{tabular}{|c|c|c|c|c|c|c|c|}
\hline \multirow{3}{*}{ Галузь } & \multicolumn{6}{|c|}{ Підприємства } & \multirow{3}{*}{ Всього } \\
\hline & \multicolumn{2}{|c|}{ Великі } & \multicolumn{2}{|c|}{ Середні } & \multicolumn{2}{|c|}{ Малі } & \\
\hline & Обсяг & $\begin{array}{c}\text { Частка, } \\
\%\end{array}$ & Обсяг & $\begin{array}{c}\text { Частка, } \\
\%\end{array}$ & Обсяг & $\begin{array}{c}\text { Частка, } \\
\%\end{array}$ & \\
\hline $\begin{array}{l}\text { Сільське, лісове та } \\
\text { рибне господарство }\end{array}$ & 38,9 & $8,31 \%$ & 238,2 & $50,93 \%$ & 190,6 & $40,76 \%$ & 467,6 \\
\hline Промисловість & 1,54 & $53,71 \%$ & 1,09 & $38,25 \%$ & 230,1 & $8,04 \%$ & 2862,3 \\
\hline $\begin{array}{l}\text { Оптова та роздрібна } \\
\text { торгівля }\end{array}$ & 873,3 & $26,06 \%$ & 1479,3 & $44,14 \%$ & 998,6 & $29,80 \%$ & 3351,2 \\
\hline $\begin{array}{l}\text { Транспорт, складське } \\
\text { господарство, поштова } \\
\text { та кур’єрська діяльність }\end{array}$ & 222,7 & $46,49 \%$ & 149,03 & $31,11 \%$ & 107,3 & $22,39 \%$ & 479,01 \\
\hline $\begin{array}{l}\text { Інформація та } \\
\text { телекомунікації }\end{array}$ & 42,6 & $19,65 \%$ & 55,56 & $25,63 \%$ & 118,6 & $54,72 \%$ & 216,8 \\
\hline $\begin{array}{l}\text { Фінансова та страхова } \\
\text { діяльність }\end{array}$ & - & & 45,8 & $67,59 \%$ & 21,96 & $32,41 \%$ & 67,8 \\
\hline $\begin{array}{l}\text { Охорона здоров’я та } \\
\text { надання соціальної } \\
\text { допомоги }\end{array}$ & - & & 12,4 & $57,66 \%$ & 9,11 & $42,34 \%$ & 21,5 \\
\hline
\end{tabular}

Джерело: розраховано автором на підставі опрацювання [2]

На жаль, не оприлюднюються дані за діяльністю в таких сферах, як будівництво, освіта, професійна, наукова та технічна діяльність. Зокрема малі підприємства останньої в 2017 р. реалізували продукції на 86,93 млрд грн, що свідчить про прагнення до розвитку на інноваційних засадах, але за відсутності повних даних не можна зробити висновок щодо спроможності МСП відповідати світовим трендам розвитку наукової та інноваційної інфраструктури.

Аналіз результатів економічної діяльності МСП протягом 2010-2017 pp. (рис. 3, 4) показав, що найбільш складним був період 2014-2015 років, коли країна відчула наслідки економічної кризи.

Оцінити стан розвитку сектору МСП можливо за допомогою коефіцієнту його активності за методикою Є.В. Романенка [4, с.94], а саме:

$$
\mathrm{K}_{\mathrm{p}}=\sqrt[n]{\text { ЧВВП } \cdot \text { ЧМП } \cdot \text { ДП } \cdot \text { ЧЗ }},
$$

де ЧВВП - частка обсягу виробленої продукції сектором МСП у ВВП, ЧМП - частка МСП від загальної кількості підприємств, ДП - частка єдиного податку для суб'єктів малого підприємництва в доходах місцевих бюджетів, ЧЗ - частка зайнятих у секторі МСП від загальної кількості, $\mathrm{n}$ - кількість показників, що використовується для розрахунків. 


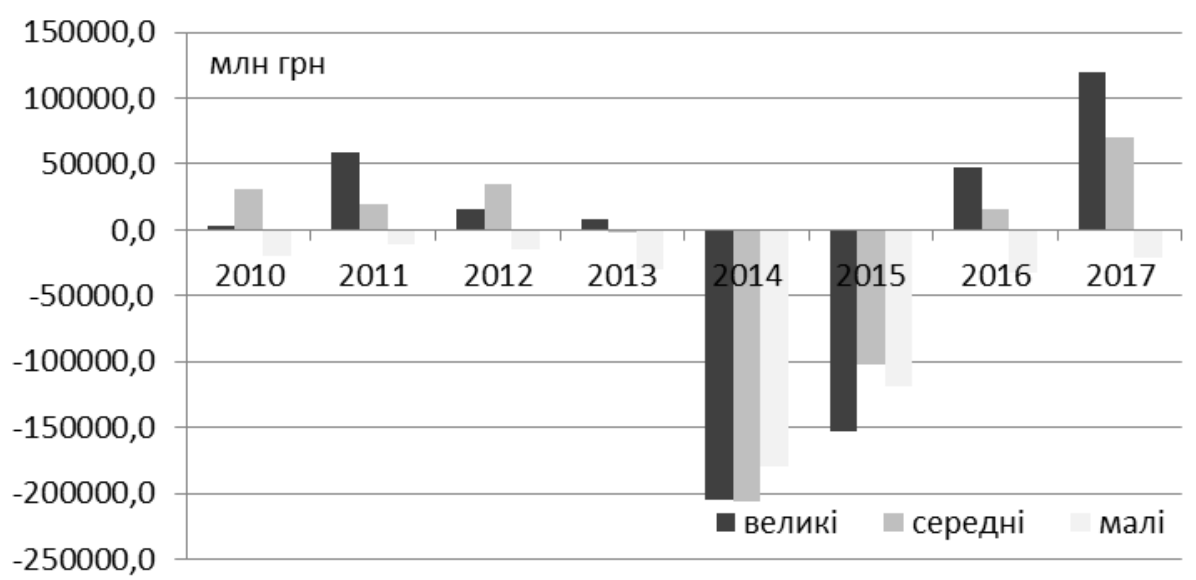

Рис. 3 Чистий прибуток (збиток) МСП протягом 2010-2017 рр., млн.грн

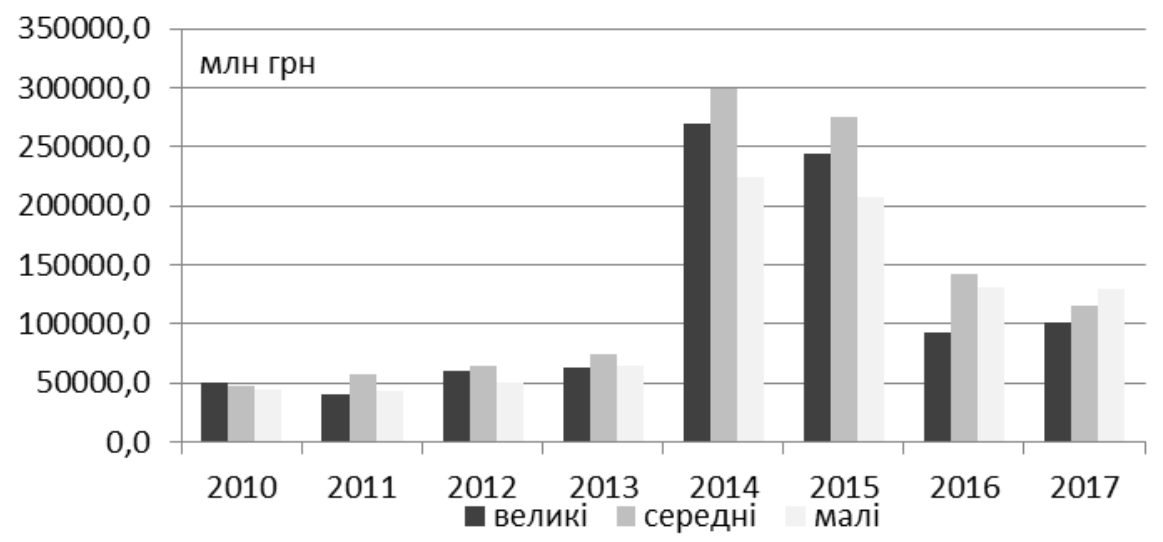

Рис. 4 Фінансовий результат протягом 2010-2017 рр., млн.грн Джерело: побудовано за даними [3]

За офіційними статистичними даними було проведено розрахунок коефіцієнту активності сектору МСП в Україні за 2010-2017 рр. (рис. 5). Поступове збільшення цього коефіцієнту вказує на тенденцію підвищення активності діяльності сектору МСП, але досить повільними темпами. Підвищення активності в останні роки відбулось внаслідок зменшенням кількості великих підприємств i збільшенням мікропідприємств, а також значним збільшенням кількості зайнятих, частки єдиного податку для суб'єктів малого підприємництва в доходах місцевих бюджетів 32014 р. Такий підхід можна запровадити для визначення та співставлення рівнів розвитку МСП у різних регіонах України та здійснення ïx кластеризації за значенням коефіцієнту активності на такі типи: аутсайдери - низький темп розвитку МСП; надійно стабільні - стійкий розвиток, що характеризується ефективною його підтримкою державою на регіо-нальному рівні; лідери активний розвиток, привабливість регіону для ведення бізнесу. 


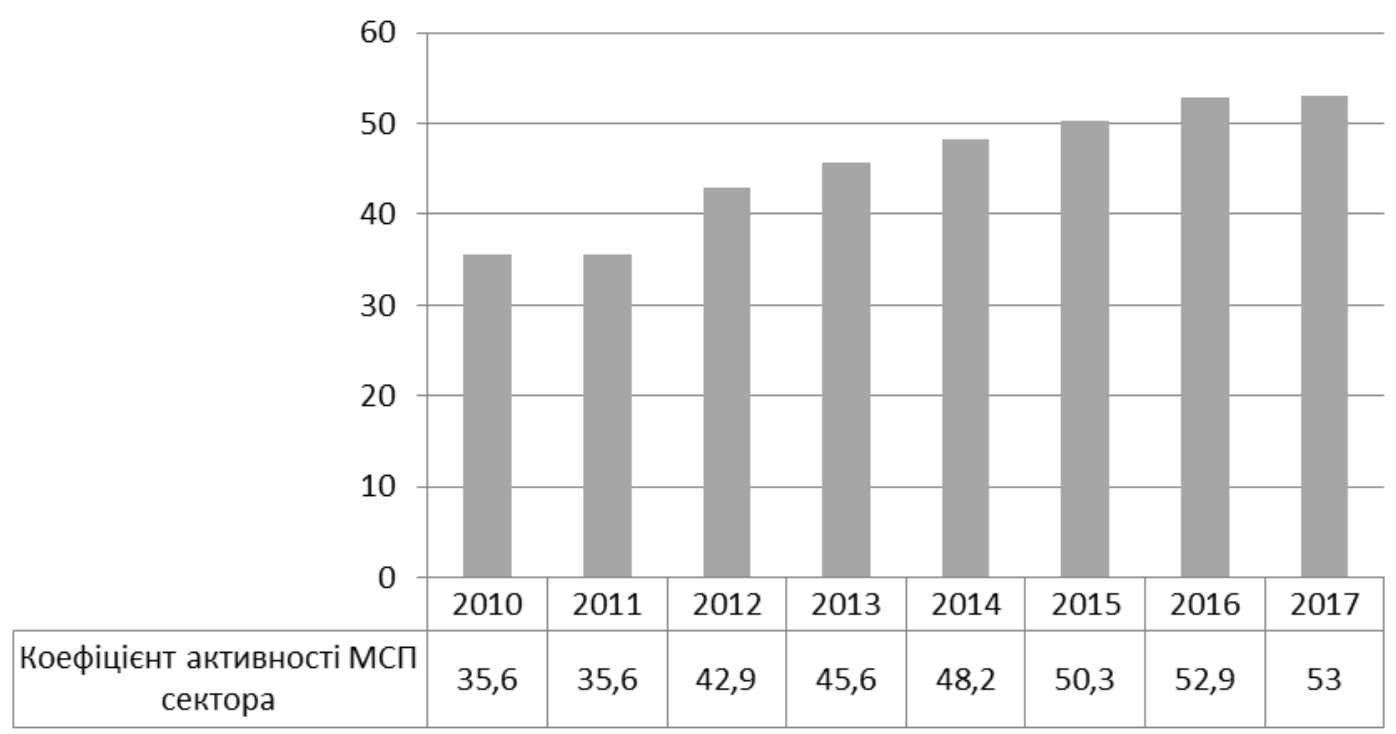

Рис. 5 Коефіцієнт активності МСП сектора України протягом 2010-2017 pp. Дожерело: розрахунок авторів

Поступове збільшення цього коефіцієнту вказує на тенденцію підвищення активності діяльності сектору МСП, але досить повільними темпами. Підвищення активності в останні роки відбулось внаслідок зменшенням кількості великих підприємств і збільшенням мікропідприємств, а також значним збільшенням кількості зайнятих, частки єдиного податку для суб'єктів малого підприємництва в доходах місцевих бюджетів 32014 р. Такий підхід можна запровадити для визначення та співставлення рівнів розвитку МСП у різних регіонах України та здійснення їх кластеризації за значенням коефіцієнту активності на такі типи: аутсайдери - низький темп розвитку МСП; надійно стабільні - стійкий розвиток, що характеризується ефективною його підтримкою державою на регіональному рівні; лідери - активний розвиток, привабливість регіону для ведення бізнесу.
Складне макроекономічне середовище потребує від МСП не тільки постійного зміцнення фінансової стійкості, але також набуття i безперервного розвитку компетенцій ринкової міцності та конкурентоспроможності, вишукуючи, займаючи i завойовуючи власну ринкову нішу i споживача. За таких обставин подальший розвиток МСП повинно передбачити інновації у виробничій діяльності, грунтуючись на наукових дослідженнях i розробках, будувати гнучкі бізнес-моделі, формувати стратегічні галузеві альянси, здійснювати оперативну реорганізацію в бік посилення інформа-ційних структур і технологій задля оптимізації операційних бізнес-процесів та прийняття ефективних управлінських рішень тощо.

Говорячи про подальший розвиток МСП в Україні та поширення інновацій у практиці фінансування, звернемо увагу, в першу чергу, на активізацію спеціальних програм, які 
пропонують 75\% вітчизняних банків. Частка МСП в їх загальному кредитному портфелі вже перевищила $52 \%$, а сума виданих кредитів у 2018 р. зросла до 436 млрд грн, де високу активність мають державні банки (ПриватБанк, Ощадбанк і Укргазбанк) та банки 3 іноземним капіталом (Райффайзен Банк Аваль, Креди Агриколь Банк, Кредобанк, ОТП Банк). Пропозиції банків для МСП достатньо широкі і дещо різняться стосовно умов фінансування (табл. 2).

Таблиця 2

Характеристичні умова фінансування МСП вітчизняними банками

\begin{tabular}{|c|c|c|c|}
\hline Характеристика & АТ «Ощадбанк» & $\begin{array}{c}\text { ПАТ КБ } \\
\text { «Приватбанк» }\end{array}$ & $\begin{array}{c}\text { Райффайзен Банк } \\
\text { Аваль }\end{array}$ \\
\hline кредитний продукт & Будуй своє & $\begin{array}{l}\text { Країна успішного } \\
\text { бізнесу (КУБ) }\end{array}$ & МійБізнес \\
\hline пропозиція & $\begin{array}{l}\text { кредитна лінія, } \\
\text { поповнення обігових } \\
\text { коштів; кредит на } \\
\text { придбання } \\
\text { транспорт-них } \\
\text { засобів та облад- } \\
\text { нання; овердрафт; } \\
\text { послуга «авто-овер»; } \\
\text { кредит під депозит; } \\
\text { банківські гарантії }\end{array}$ & $\begin{array}{l}\text { кредитна лінія, } \\
\text { поповнення обігових } \\
\text { коштів; овердрафт; } \\
\text { кредит під депозит; } \\
\text { бізнес-іпотека, } \\
\text { інвестиційний } \\
\text { кредит, }\end{array}$ & $\begin{array}{l}\text { кредитна лінія, } \\
\text { інвестиційний кредит } \\
\text { на придбання транс- } \\
\text { портних засобів та } \\
\text { обладнання; } \\
\text { банківські гарантії, } \\
\text { авалювання векселів; } \\
\text { партнерські програми } \\
\text { фінансування с/госп. } \\
\text { техніки, } \\
\text { енергоефективності }\end{array}$ \\
\hline валюта кредиту & $\begin{array}{c}\text { гривня, долар США, } \\
\text { євро }\end{array}$ & $\begin{array}{c}\text { гривня, долар США, } \\
\text { євро }\end{array}$ & гривня, євро \\
\hline строк кредиту & до 3 років & до 3 або 5 років & від 1 до 5 років \\
\hline $\begin{array}{l}\text { відсоткова ставка в } \\
\text { національній валюті }\end{array}$ & від 18,2\% & $\begin{array}{l}\text { 1,8\% (1-6 місяць), } \\
1,6 \% \text { (7-12 місяць), }\end{array}$ & від 20\% \\
\hline комісія при видачі & від $0,2 \%$ & $0 \%$ & $0,50 \%-0,99 \%$ \\
\hline застава & $\begin{array}{c}\text { нерухоме та рухоме } \\
\text { майно, майнові } \\
\text { права, порука }\end{array}$ & $\begin{array}{c}\text { нерухоме та рухоме } \\
\text { майно, } \\
\text { с/господарська } \\
\text { техніка, порука }\end{array}$ & $\begin{array}{c}\text { нерухоме та рухоме } \\
\text { майно, майнові права } \\
\text { на депозит }\end{array}$ \\
\hline $\begin{array}{l}\text { власна участь у } \\
\text { фінансуванні } \\
\text { проектів }\end{array}$ & & & $\begin{array}{c}\text { від 20\% вартості } \\
\text { проекту }\end{array}$ \\
\hline
\end{tabular}

Джерело: сформовано на підставі опращювання інформації відповідних банків

Компаративний аналіз таких пропозицій показав, що державні банки спеціалізуються на аграрному секторі, транспорті, житлово-комунальному господарстві, підтримують проекти, які спрямовані на енергоефективність, енергозбереження, екологічність, ви- користовуючи фінансові інструменти - банківські гарантії, бланкові та залогові овердрафти, авалювання векселів, кредити під депозит тощо [5]. Бачимо, що вартість фінансування досить висока, що $\epsilon$ наслідком жорсткої монетарної політики 
Національного банку, який протягом 2018 p. неодноразово підвищував облікову ставку з 16\% до 18\% річних.

Bce означене змушує МСП для вирішення питання фінансування звертатись за інвестиціями до МФО, зокрема СБРР, Німецько-українського фонду, СІБ, KFW та ін. [6].

\section{Таблиця 3}

Проекти МФО щодо фінансування вітчизняних МСП

\begin{tabular}{|c|c|c|c|}
\hline Роки & МФО & Сума кредитування, проекти & Банки-партнери \\
\hline \multirow{3}{*}{$\begin{array}{l}2006- \\
2008\end{array}$} & СБРР & 140 млн. дол. США, 4 проекти & $\begin{array}{l}\text { ПАТ «Райффайзен Банк Аваль» } \\
\text { ПАТ «Мегабанк» } \\
\text { ПАТ «Укрсиббанк» } \\
\text { ПАТ «ПроКредит Банк» }\end{array}$ \\
\hline & МФК & 90 млн. дол. США, 2 проекти & $\begin{array}{l}\text { ПАТ «ПроКредит Банк» } \\
\text { ПАТ «SwedBank» }\end{array}$ \\
\hline & ЧБТР & 32,5 млн. дол. США, 3 проекти & $\begin{array}{l}\text { ПАТ «ПроКредит Банк» } \\
\text { ПАТ «Банк «Південний»»» }\end{array}$ \\
\hline \multirow{2}{*}{2009} & МФК & 20 млн. дол. США & ПАТ «Мегабанк» \\
\hline & ЕІБ & 100 млн.євро & ПАТ «БАНК ФОРУМ» \\
\hline 2011 & ЕБРР & $\begin{array}{l}100 \text { млн. дол. США, «Українська } \\
\text { програма кредитування малого та } \\
\text { середнього бізнесу» }\end{array}$ & ПАТ «Укрексімбанк» \\
\hline 2012 & ЄІБ & 660 млн. євро, 4 проекти & $\begin{array}{l}\text { ПАТ «Укрексімбанк» } \\
\text { ПАТ «UniCredit» } \\
\text { ПАТ «Промінвестбанк» } \\
\text { ПАТ «Ощадбанк» }\end{array}$ \\
\hline \multirow[t]{2}{*}{2014} & ЄІБ & $\begin{array}{l}400 \text { млн. євро програма } \\
\text { «Кредитування малих та середніх } \\
\text { підприємств» }\end{array}$ & \\
\hline & ЧБТР & 2,5 млн. дол. США & ПАТ «Банк Восток» \\
\hline 2017 & ЕІБ & 60 млн. євро & ПАТ «ПроКредит Банк» \\
\hline
\end{tabular}

Джерело: сформовано на підставі опрацювання [7]

Розвиток цифрових технологій призвів до трансформації фінансового посередництва та, водночас, посилення конкуренції між фінансовими посередниками щодо надання фінансових послуг [8].

На увагу заслуговують також альтернативні інструменти фінансування МСП, що мають інноваційний характер i зараз набувають поширення, $\epsilon$ крауд-технології, які відкривають он-лайн доступ для акумулювання фінансових ресурсів та реалізовані в таких формах:
1) краудлендінг або р2pкредитування - фінансування через інтернет-майданчики, де розміщуються кредитні заявки, реєструються кредитори i позичальники, якими $є$ фізичні особи, формується кредитний рейтинг позичальника, на основі якого визначається відсоткова ставка та термін надання кредиту. Для інвестора - це можливість першим отримати продукт зі знижкою, подарунки, привілеї. Таке фінансування $\epsilon$ альтернативою банкам i мікро- 
фінансовим установам, адже його вартість значно нижче за рахунок низьких трансакційні витрати та спрощеного документообігу, крім того $\epsilon$ варіанти стосовно застави. Перспективи розвитку такого фінансування оцінюється світовими аналітиками в 300 млрд дол США до 2020 p. На сьогодні в Україні на цьому ринку працюють платформи Каштан 2000 i Finstream у складі фінансової компанії FGK Financial Group, Finhub від ООО «КУ «Фінкредит плюс» i Advance Finance Alliance [9];

2) краудінвестінг здійснюється на відкритих цифрових платформах колективного або прямого проектного фінансування, принциповою відмінністю якого $\epsilon$ залучення мікроінвесторів 3 подальшою участю в акціонерному капіталі стартапкомпанії (акціонерний підхід), коли останні не можуть розраховувати на банківську та венчурну підтримку, адже вони невеликі за розмірами, не мають власної кредитної історії, їх бізнес-плани недосконалі тощо [10]. Якщо краудінвестінг здійснюється на принципах роялті, то мікроінвестори отримають частку прибутку залежно від суми власних інвестицій за умови успіху стартапу. В Україні працюють платформи Big Idea, UInvest та NaStarte, зокрема останньою зібрано 12,116 млн грн від більш ніж 50 тис. мікроінвесторів 3 середнім чеком 390 грн [11].

Висновок. Отже, сектор МСП має значний потенціал для забезпечення сталого розвитку національної економіки. Водночас, він потребує стійкого фінансування для чого з боку фінансових посередників очікується впровадження нових механізмів, технологій, спеціальних інструментів і стимулів інвестиційного кредитування. Все означене разом зі сприятливим бізнес-кліматом дозволить Україні скоріше набути економічну стабільність і зростання.

\section{Список використаної літератури}

1. Про схвалення Стратегії розвитку малого і середнього підприємництва в Україні на період до 2020 року. Розпорядження КМ України від 24 травня 2017 p. № 504-p URL: http://zakon.rada.gov.ua/laws/show/504-2017-\%D1\%80 (дата звернення: 12.02.2019).

2. Діяльність підприємств. Офіційна сторінка Державної служби статистики України. URL: http://www.ukrstat.gov.ua/ (дата звернення: 12.02.2019).

3. Офіційна статистика МСП в Україні: аналіз та пропозиції щодо вдосконалення. URL: http://www.ier.com.ua/files/Projects/2015/LEV/pp_SME_statistics_2017.pdf (дата звернення: 12.02.2019).

4. Романенко Е.В. Малое предпринимательство в Омской области. Российское предпринимательство. 2008. № 11. С. 93-96. 
5. Банківські продукти та програми допомоги малому i середньому підприємництву URL: http://www.me.gov.ua/Documents/Detail?lang=ukUA\&id=aba8ec4d-7a97-4b6c-9065-22aae227d6d7\&title=BankivskiProdukti TaProgramiDopomogiMalomuISerednomuPidprimnitstvu\&isSpecial=true (дата звернення: 15.02.2019).

6. Пантєлєєва К.О. Інвестиційно-кредитна підтримка розвитку малого та середнього підприємництва міжнародними фінансовими організаціями. Вісник Одеського національного університету. Серія «Економіка». 2018. Т.23. Випуск 6(71). C. 148-153.

7. The EBRD in Ukraine. URL: https://www.ebrd.com/ukraine.html (accessed 15 Feb. 2019) [in Eng].

8. Pantielieieva N., Krynytsia S., Khutorna M., Potapenko L. (2018) FinTech, Transformation of Financial Intermediation and Financial Stability. Proceedings of the International Scientific-Practical Conference «Problems of Infocommunications. Science and Technology» (Ukraine, Kharkiv, 9-12 October 2018). Kharkiv: IEEE , pp.553-559. doi: 10.1109/INFOCOMMST.2018.8632068 [in Eng].

9. В Україні з'явилася перша платформа Р2Р-кредитування finance.ua https://news.finance.ua/ua/news/-/420417/v-ukrayini-zyavylasya-persha-platformap2p-kredytuvannya (дата звернення: 15.02.2019)

10. Краудінвестинг в Україні URL: https://moneyveo.ua/uk/article/kraudinvesting/ (дата звернення: 15.02.2019)

11. Na-Starte. URL: http://na-starte.com/about (дата звернення: 15.02.2019) 